IZA DP No. 8682

New Directions in Immigration Policy:

Canada's Evolving Approach to the

Selection of Economic Immigrants

Ana Ferrer

Garnett Picot

W. Craig Riddell

November 2014 


\title{
New Directions in Immigration Policy: Canada's Evolving Approach to the Selection of Economic Immigrants
}

\author{
Ana Ferrer \\ University of Waterloo \\ Garnett Picot \\ Queen's University
}

W. Craig Riddell

University of British Columbia

and IZA

Discussion Paper No. 8682

November 2014

\author{
IZA \\ P.O. Box 7240 \\ 53072 Bonn \\ Germany \\ Phone: +49-228-3894-0 \\ Fax: +49-228-3894-180 \\ E-mail: iza@iza.org
}

Any opinions expressed here are those of the author(s) and not those of IZA. Research published in this series may include views on policy, but the institute itself takes no institutional policy positions. The IZA research network is committed to the IZA Guiding Principles of Research Integrity.

The Institute for the Study of Labor (IZA) in Bonn is a local and virtual international research center and a place of communication between science, politics and business. IZA is an independent nonprofit organization supported by Deutsche Post Foundation. The center is associated with the University of Bonn and offers a stimulating research environment through its international network, workshops and conferences, data service, project support, research visits and doctoral program. IZA engages in (i) original and internationally competitive research in all fields of labor economics, (ii) development of policy concepts, and (iii) dissemination of research results and concepts to the interested public.

IZA Discussion Papers often represent preliminary work and are circulated to encourage discussion. Citation of such a paper should account for its provisional character. A revised version may be available directly from the author. 
IZA Discussion Paper No. 8682

November 2014

\section{ABSTRACT}

\section{New Directions in Immigration Policy: Canada's Evolving Approach to the Selection of Economic Immigrants}

Canada's immigration system is currently undergoing significant change driven by several goals that include (1) a desire to improve the economic outcomes of entering immigrants; (2) an attempt to better respond to short-term regional labor market shortages often associated with commodity booms, and (3) a desire to shift immigration away from the three largest cities to other regions of the country. These goals reflect the implementation of new immigration programs in the 2000s. The paper discusses the recent changes to Canadian immigration policy, examines preliminary evaluations of the new programs and discusses potential future issues emanating from the changes.

JEL Classification: J11, J24, J61, J68

Keywords: migration, immigration policy, immigrant selection, points system, human capital, temporary foreign workers

Corresponding author:

W. Craig Riddell

Department of Economics

University of British Columbia

\#997 - 1873 East Mall

Vancouver, B.C.

Canada V6T 1 Z1

E-mail: craig.riddell@ubc.ca

\footnotetext{
* Pre-publication version of an article published in the International Migration Review. We thank the editor and referees for comments that improved the paper. We have also benefited from comments of Charles Beach, Mikal Skuterud, Casey Warman and Chris Worswick and financial support from the SSHRC.
} 


\section{Introduction}

Support for immigration remains strong in Canada, in spite of the recent economic slowdown. This feature differentiates Canada from many developed western nations. The positive support for continued high immigration levels by governments, the business community and the public in Canada is driven in part by the belief that economic challenges associated with the retirement of the 'baby boom' generation will be lessened by maintaining immigrant inflows at high levels. ${ }^{1}$ Related concerns regarding selective skill shortages motivated by commodity booms, and longer- term aggregate labour shortages also play an important role in generating public support. While opinions are divided among analysts as to whether immigration can or should be used to address such shortages, if in fact they materialize, public and governmental support remains strong. Within this context, the immigration system has undergone dramatic change in the 2000 s, becoming much more complex and involving many more programs and players in an attempt to better meet stated goals. This change has focused almost exclusively on the Economic Immigrant Class, with much less policy development involving the family and refugee classes. Hence, this paper concentrates on the selection of economic immigrants.

Canada is one of the world's main immigrant destinations, with approximately 200,000 to 250,000 immigrants arriving annually in recent years. Canada and Australia have the highest immigration rates in the western world, admitting approximately 0.8 percent of their populations annually. In 1962 Canada abandoned the long-standing policy of "preferred" and "non-preferred" source countries in favour of basing admission on individual applicants' personal characteristics, especially education and skill qualifications. Beginning in the late 1960s, Canada pioneered the use of a "points system" for selecting economic migrants, an approach subsequently adopted by Australia in the 1980s and the UK in 2002. The points system applied only to «principal applicants » seeking admission as part of the "economic" class.

From the outset - and especially in recent decades - the points system has focused on selecting highly skilled immigrants. Recent immigration policy has shifted toward admitting increasing numbers in the economic class and fewer in the family reunification and refugee classes.

\footnotetext{
${ }^{1}$ Despite this belief, which appears to be widespread, most careful analyses conclude that immigration can make only modest impacts on the rate of population ageing (e.g. Beaujot, 2003).
} 
Approximately 60 percent of all immigrants to Canada are now in the "economic" class, including the principal applicants and their spouses and dependents.

The Canadian immigration system is undergoing significant change driven by a number of goals that include: (1) a desire to improve the economic outcomes of entering immigrants, given the deterioration in labour market outcomes over the past several decades; (2) an attempt to better respond to short-term regional labour market shortages often associated with commodity booms, and (3) a desire to shift immigration away from the three largest cities to other regions of the country that are seeking more economic immigrants. These goals are reflected in the modification of the point system imbedded in the Immigration and Refugee Protection Act of 2002 and the implementation of a series of new immigrant programs, including the Canadian Experience Class, the Provincial Nominee program, Ministerial Instructions, the Federal Skilled Trades program and the possibility to apply for permanent residency as temporary immigrants from the Live-inCaregiver program. Almost all of these changes relate to the selection and economic integration of "economic" immigrants. There have also been substantial changes to and increased use of the Temporary Foreign Worker program.

This paper makes three contributions. First, we describe and discuss recent changes to Canadian immigration policy regarding the selection of economic immigrants and provide the context for these changes. Our goal is to give readers an up-to-date overview of the extensive changes made to Canada's immigration policy in the past decade and an understanding of the forces underlying these developments. Second, we analyze early evaluations of the effectiveness of recent policy initiatives in achieving stated goals. The third contribution is to discuss potential future issues related to the recent changes.

\section{The Evolution of Canada's Immigration Policy}

A key theme in the evolution of immigration policy is the trade-off between short-term and longterm objectives. The introduction of the points system in the mid 1960s was seen as a means of responding to short-term labour market needs. Points were assigned to specific occupations and were reviewed on a quarterly basis as new information on perceived vacancies became available (Green and Green, 1999). There was a belief that immigration policy could be managed at detailed occupation levels. In the 1980s information from the federal government's Canadian Occupational 
Projection System, combined with that from "key informants," was used to alter the points assigned to specific occupations.

\subsection{From Selection Based on Occupational Imbalances to the Human Capital Model}

In the 1990s there was a shift away from a focus on occupational shortages and a move to provide generally higher levels of human capital to meet labour market needs. The main reason behind this shift was the considerable difficulty in managing occupation-based selection. It was difficult to obtain reliable information on occupational imbalances, or to select immigrants in each desired occupation. Note that points assigned to occupations were based on the immigrant's "intended occupation," but there is no requirement that new arrivals work in their intended occupation. It was also problematic to respond quickly to short-term or localized shocks as immigrants are free to settle wherever they wish, and most settled in one of the three largest cities. In addition, because of the long application backlog, short-term shortages may have been resolved by the time immigration applications have been processed.

In the early 1990s the points system was adjusted to increase the importance of general human capital characteristics, notably education, in the selection process. The "human capital" model of selection took a longer run perspective, focusing on characteristics believed to be important determinants of longer-term economic outcomes. The result was a rapid rise in the educational attainment of immigrants through the $1990 \mathrm{~s}^{2}$ There was also an increase in the share of immigrants in the economic class, in part in response to the high tech boom of the late 1990s. With the new Immigration and Refugee Protection Act (IRPA) legislation introduced in 2002, Citizenship and Immigration Canada (CIC) moved completely away from the attempt to meet short-term labour market objectives through the Federal Skilled Worker (FSW) program (selection based on points). Instead, they strengthened the "human capital" model of immigration that rewarded skills such as education, experience and language ability, rather than specific occupations. The idea was that these

\footnotetext{
${ }^{2}$ In the 1980 s, approximately 10 percent of all entering immigrants aged 15 and over had a university degree; by 2005 it was 45 percent. Fully 78 percent of principal applicants to the Federal Skilled Worker program (the main program for economic immigrants at that time) admitted over the 2000 to 2007 period had a university degree, as did about one half of their spouses. But even in other immigrant classes educational attainment was moderately high: 27 percent in the family class had degrees, as did 13 percent among refugees. If one focuses on the population aged 25 to 54 , in 2006 around 60 percent of all male and 50 percent of female entering immigrants had university degrees.
} 
key characteristics, particularly education, would allow immigrants to better adjust to both cyclical and structural labour market change, thereby improving longer-term immigrant economic outcomes.

However, since the mid 2000s there has been a rebalancing of the objectives, brought about in part by the issue of declining economic outcomes among entering immigrants and the need to address regional and occupational labour shortages. There has been renewed emphasis on meeting short-term labour market needs. However, the "points system" imbedded in the FSW program is not being used to address these objectives. Rather, new programs are being developed or expanded.

\subsection{The Deteriorating Labour Market Outcomes of Immigrants in Canada}

Over the past three decades the economic outcomes of immigrants, relative to the native born, have deteriorated significantly. For example, male immigrants entering during the late 1970s had annual earnings that were roughly 85 percent of that of their Canadian born counterparts during the first five years in Canada. By the early 1990s this number had fallen to 60 percent. It improved some during the late 1990s, but fell again in the early 2000s. Poverty rates reflected this deterioration. Among "recent" immigrants - in Canada for less than 5 years - the poverty rate rose from 25 percent in 1980 to 45 percent in 1995. Fortunately there has been some improvement since then as the rate fell to 32 percent by 2010, with considerable improvement in the 2000s (Hou and Picot, 2014). However, the poverty rate also fell among the general population during the 2000s, so the recent immigrant poverty rate remains about 2.7 times that of the general population, well above the 1.4 times observed in the early $1980 \mathrm{~s}$.

A number of studies have focused on the reasons for the rise in the earnings gap between recent immigrant cohorts and the Canadian born (Reitz 2003; Sweetman 2003; Aydemir and Skuterud 2005; Ferrer, Green and Riddell 2006; Ferrer and Riddell 2008; Picot and Hou, 2009; Green and Worswick 2010, 2012). These studies point to explanations such as the changing source regions of entering immigrants, declining returns to foreign labour market experience, deterioration in the outcomes for new labour market entrants in general, education quality, language skills and sectoral economic downturns (see Reitz, 2007 and Picot and Sweetman 2005, 2011 for reviews). Perhaps most importantly, language skills appear to mediate the rate of return to formal education. Immigrants with good language skills in English or French can much more easily convert their education to earnings than those with poor skills. Work by Bonikowska, Green and Riddell (2008) 
has shown that when literacy and numeracy skills in English or French are accounted for, immigrants earn about what one would expect, and have earnings similar to their comparable Canadian born counterparts. ${ }^{3}$ Overall, language skills appear to have a significant direct and indirect influence on labour market outcomes, and are key to positive outcomes.

Other factors such as labour market discrimination and the lack of credential recognition no doubt play a role in the poor outcomes of some immigrants. For example, Oreopoulos (2011) finds that job applicants with ethnic surnames are less likely to obtain an interview than their counterparts with Anglo-Saxon surnames, and otherwise identical characteristics. However, there is little evidence that these factors contributed to the deterioration of immigrant economic outcomes.

Given this body of research, Canadian policy makers have put considerable effort into improving labour market outcomes of economic immigrants. During the early 1990s the points system was altered to increase the share of immigrants with higher education, and the share of immigrants in the economic class. In the early 2000s the new selection grid imbedded in the IRPA legislation focused on characteristics that promote longer run labour market adjustment, and the applicant's ability to successfully move from job to job as the labour market changes (i.e. the human capital model). Labour market research was also instrumental in the development of the Canadian Experience Class (CEC), which focuses on potential immigrants who already have some Canadian experience, thus reducing issues related to credentials recognition and lack of Canadian experience.

\section{IRPA and the Rebalancing of Longer Run and Short-Term Objectives.}

The current selection system for economic immigrants selected by the federal government was introduced by passage of IRPA in 2002. The human capital model of selection replaced the focus on "occupations in demand" in the federal program. The new selection criteria were based on research and extensive consultations. Table 1 shows the pre-IRPA and post-IRPA point grids.

An additional important change relates to the awarding of language points. Under the IRPA regime, principal applicants to the main federal economic programs must now take an approved

\footnotetext{
${ }^{3}$ These skill measurements are carried out in one of Canada's official languages, and thus cannot distinguish between poor literacy skills in general and the ability to apply one's literacy skills in English or French. This is also the case to a lesser extent for numeracy skills.
} 
language test and submit the results. There is a minimum requirement for each program, with the bar for the FSW and CEC class being quite high, and that for the Federal Skilled Trades (FST) workers somewhat lower. The language requirements for the Provincial Nominee (PN) programs vary considerably. Some streams and some provinces have language requirements, others do not, and the requirements vary among streams. In an evaluation of the PN programs, CIC (2011) indicated some concern with this situation and the lack of minimum language requirements.

Researchers have recently evaluated the effects of these changes to the points system on labour market outcomes. Beach, Green, and Worswick $(2008,2012)$ analyse the impacts of immigration "policy levers" on immigrants' human capital characteristics (years of schooling, age at arrival, and language proficiency). The policy levers are the overall level of immigration flows, the percent of the total that is admitted under the economic class, and the points assigned for specific attributes (education, age and language). They conclude that variations in these policy levers - especially increased emphasis on the economic class and increased points assigned to education -- do influence the characteristics of immigrants and do result in improved immigrant outcomes. Picot and Hou (2009) also assessed the effect on immigrant earnings of the rising share of immigrants in the economic class and with a university education that stemmed from earlier (1993) changes to the points system. They concluded that these rising shares did improve average earnings during the first few years in Canada.

The introduction of IRPA in 2002 provided a unique opportunity to make a direct comparison between two alternative policy regimes. Begin, Goyette and Riddell (2010) studied the impact of the IRPA policy change on short-term immigrant employment and earnings outcomes over the period 2002 to 2006. New immigrant arrivals admitted under the IRPA selection regime were found to earn between 21 percent and 46 percent more (depending on the cohort and taxation year) than their counterparts who were admitted in the same year under the pre-IRPA selection system.

These studies suggest that in the future we might see greater economic success among economic immigrants selected under the federal points system.

\section{Broadening the Goals of Immigration: Recent Policy Developments}


New concerns about the appropriateness of Canada's immigration policy emerged around the turn of the century, notably claims about "labour shortages. ${ }^{4}$ These concerns were prompted in part by (1) the development of tight labour markets in parts of Canada associated with the recent commodity boom (temporarily halted by the 2008-2009 recession), (2) the perceived need by many provinces for additional immigrant labour to promote population and labour force growth, and (3) a widespread belief that an aggregate labour shortage will develop over the coming years, and that continued immigration is required for economic and population growth.

But rather than turn to the point system to achieve a rebalancing of objectives, the Canadian government looked to new programs developed in partnership with, or exclusively by, the provinces. These programs generally increase the participation by the provincial governments and employers in the selection of immigrants, increase the use of temporary foreign workers (and the opportunity for some of them to become permanent residents), and give the federal government more authority to control the flow of immigrants of particular types (e.g. in particular occupations). Many immigrants entering via these programs have lower levels of education than previous immigrants -- in 2010, about $80 \%$ of new FSWs had a university degree, compared with 47 percent among PNs - and pre-arranged jobs, and hence the short-term needs of employers are imbedded in the selection process. These differences show up in the "intended occupation" declared by entering immigrants. Roughly 90 percent of entering FSWs and 50 percent of PNs selected trades, semiskilled or unskilled occupations as their intended occupations (CIC 2011). ${ }^{5}$

In addition, the old entrepreneurship programs (Immigrant Investor and Federal Entrepreneur Programs) have been suspended and a pilot program (Start Visa program) set in place to attract investment and innovation to Canada.

Although it is too early to fully assess these changes in immigration policies, the results of studies completed to date are cautiously optimistic regarding their effect on the economic outcomes of immigrants, at least in the short-term. We review this evidence below.

\subsection{Provincial Nominee program}

\footnotetext{
${ }^{4}$ Whether labour shortages in fact exist is a matter of dispute. Employer groups frequently report difficulties hiring suitable workers, but other evidence, such as large discrepancies between job vacancies and unemployed workers or substantial wage increases, is scarcely documented.

${ }^{5}$ This does not mean that either the FSWs or the PNs in fact work in these occupations, particularly during their early years in Canada. They may end up in other occupations.
} 
Immigration is a shared federal and provincial responsibility. The federal government has taken the lead role through most of Canada's history, although for many years the province of Quebec has had its own skilled worker program, and is largely responsible for selecting its own immigrants. More recently other provinces are playing a role in immigrant selection, primarily through the Provincial Nominee (PN) program. This program has two basic objectives (i) to locate more immigrants in the regions and provinces outside of the three major cities, and (ii) to meet the workforce needs of employers in those provinces, often short-term labour market needs.

The PN program is relatively new and therefore evaluation of its effectiveness is limited. Pandey and Townsend (2011) find that the PN programs introduced by Manitoba, PEI and New Brunswick are associated with significant increases in immigration inflows into those provinces, achieving one of the program's goals. Furthermore, the one-year retention rates of recent immigrants did not decrease following the introduction of PN programs in provinces that adopted this approach. This evidence suggests that this may be an effective way of attracting and retaining immigrants to specific regions. CIC (2011) examines all eleven Provincial and Territorial Nominee programs and finds generally favourable evidence on retention in the western provinces, with less desirable outcomes in the Atlantic provinces. ${ }^{6}$

Several studies compare the earnings of economic immigrants admitted under the PN program with those admitted under the FSW program. Results regarding entry earnings are generally favourable for the PN programs, as one might expect since many have pre-arranged jobs. But there is again some variation across regions as well as across other characteristics such as educational attainment. The CIC evaluation finds that initial earnings (one year after arrival) of PNs tend to be higher than those of FSWs but the earnings of the latter group grow more rapidly during the first five years after arrival (CIC 2011). Pandey and Townsend (2012) find considerable regional variation in the extent to which the short-run earnings of PNs exceed those of the FSWs. Zhang (2012) studied the B.C. PN program and found dramatic differences in initial earnings between B.C. PNs and FSWs who settle in B.C. The earnings gap narrows somewhat over time, but, controlling for individual characteristics, remains very large - a gap of over $50 \%$-- even five years after arrival.

\footnotetext{
${ }^{6}$ Overall provincial retention rates were over 80 percent for PNs admitted during the period 2000 to 2008 but retention did vary regionally, with rates over 95 percent in B.C. and Alberta and under 60 percent in the Atlantic provinces.
} 
Hence short-term evaluations suggest that PNs achieve higher earnings than their FSW counterparts. However, under the human capital model the FSW program focuses on longer-run outcomes. Whether economic outcomes of PNs will match or exceed those of FSWs in the longer run remains to be seen.

\subsection{Temporary Foreign Worker program}

The Temporary Foreign Worker (TFW) program is increasingly being used to respond to very short-term labour supply needs in specific regions. The TFW program in fact consists of many programs -- ranging from low-skilled seasonal workers, workers filling perceived shortages in unskilled or semi-skilled occupations, live-in care providers, to the very highly skilled. A list of occupations in short-term demand developed jointly by the federal and provincial ministries of immigration is used to guide the selection process. There are concerns about possible negative longrun effects of this program, related to (1) whether the temporary workers will return home or remain in Canada, (2) the possibility of unjust exploitation of the workers by a few employers, (3) whether the skill distribution of entering workers will shift towards the lower skilled group, possibly creating future labour adjustment difficulties for these workers, and (4) whether temporary workers place downward pressure on wages in affected occupations (see, for example, Alboim and Cohl, 2012).

Employers may hire TFWs after obtaining a Labour Market Opinion from Employment and Social Development Canada, which assesses whether there are Canadian workers available to fill that job as well as checking that all administrative procedures have been followed. Most foreign workers who want to work in Canada must first obtain a job offer from a Canadian employer. They then apply to CIC for a permit to work temporarily in Canada and must agree to leave Canada voluntarily. A four-year cumulative limit is imposed on many TFWs' employment in Canada. The TFW program is driven by employers, who are likely better able to assess the transferability of the worker's skills to the Canadian labour market, at least in the short run. Hence, one might expect TFWs not to encounter the same difficulty receiving returns to their foreign human capital, particularly since they enter the country with a job in place.

Research on TFWs is very limited. Warman (2006) finds that, in the aggregate, the earnings of male TFWs are higher than those of recently landed immigrants, as one would expect since they 
have a job to go to. Warman (2010) also finds some evidence that these immigrants, in the short run at least, not only receive larger returns to their foreign schooling, but also receive large positive returns to their foreign experience compared to the low returns experienced by other similarly skilled economic immigrants. This suggests that the TFW program may enhance the ability of foreign-born workers to obtain recognition for their foreign acquired human capital in the Canadian labour market. Sweetman and Warman (2009) also find that, among FSW principal applicants, those who were previously TFWs initially have better earnings and employment outcomes than immigrants without previous Canadian human capital. However, this advantage seems to disappear four years after landing.

\subsection{Canadian Experience Class program}

The CEC was introduced in 2008. It allows some skilled temporary workers as well as international students with a Canadian degree and at least one year of Canadian work experience to apply for permanent status without leaving the country. The program is sizeable. In recent years, around 30,000 applicants to permanent residency made the transition from TFW or International Student temporary status. This feature is in accordance with the longer run objectives of the new immigration policies to promote selection into permanent residency for adaptable workers. Other TFWs such as the seasonal agricultural worker program have very strict regulations with a trivially low percentage of workers ever transiting to permanent status.

The CEC approach is in contrast to the use of a point system that uses observable characteristics to predict labour market success and admits individuals on that basis. The new approach gives employers - through job offers - and postsecondary institutions - through student selection - a greater role in the selection process. The involvement of employers and educational institutions may make it more likely that immigrants' foreign work experience will be valued and educational credentials will be recognized. This new program also has a language requirement that is structured differently from that for the FSW program in that, first, it assesses English or French, as opposed to English and French, and second, it is pass/fail and not an element of the points system that is combined with other factors in the assessment. An applicant with high educational attainment but poor language proficiency in English and French could gain admission under the points system, but may not be successful under the CEC due to language issues. 
While it is too early to assess the success of this new program, there has been one attempt to proxy the results of this policy. Sweetman and Warman (2009) compare the outcomes of TFWs and former international students who became permanent residents to those of immigrants that became permanent residents without previous Canadian human capital at the time of landing. Hence, although immigrants entering under CEC will likely differ from the immigrants in this study, it does offer a preview of the potential success of the CEC. The study finds that former male TFWs and international students who became permanent residents had a $61 \%$ earnings advantage over others assessed under the points system, even after controlling for observable differences.

\subsection{Ministerial Instructions}

The "Ministerial Instructions" legislation of 2008, introduced at the federal level, is also designed to increase the focus on occupational shortages, as well as reduce the applications backlog. This legislation allows the CIC Minister (and the department) to set specific controls on the number of immigrants entering in particular occupations. Ministerial instructions allow for the implementation of a set of restrictions on applications based on occupation and are issued several times a year. ${ }^{7}$ Starting in 2008, prospective principal applicants in the FSW program had to be in one of 36 occupations to be eligible to apply for admission. In June of 2010 this was reduced to 29 occupations. The approach used by CIC to arrive at the list of occupations is not transparent, and hence it is difficult to know precisely why some occupations were retained, and others dropped. This occupational "filter" was designed in part to focus immigrants in a particular set of occupations deemed to be in demand. However, it was also implemented as a means of reducing the number of applications, and reducing the very large backlog.

\subsection{Federal Skilled Trades Program}

Implemented a year ago, the program accepts skilled trades workers in 43 specific occupations that reflect the needs of the Canadian labour market. Applicants must submit proof of recent full time experience in the skilled trade, proof of language ability (Canadian Language Benchmark level 5 and 4), a valid one year offer of employment in Canada or a certificate of qualification from a province or territory in a qualifying skilled trade and that meets the employment requirements set out in the National Occupational Classification system.

\footnotetext{
${ }^{7} \mathrm{http}: / /$ www.cic.gc.ca/english/department/mi/index.asp\#mi12
} 
It is too early to assess the performance of the program, but the pre-arranged job requirement suggests that the short-term outcomes of these immigrants should be similar to those of other foreign workers admitted with similar requirements.

\section{Future Issues Emanating from Recent Policy Changes}

Extrapolating from the recent policy trends, there are a few identifiable issues that will have implications for both the research and policy communities.

\subsection{Increased Information Requirements for Policy Development}

The re-orientation described earlier will increase the demand for current labour market information and immigration research. Although a considerable body of research exists, policy analysts find little directly relevant information when attempting to determine the appropriate immigration level or immigrant mix by, say, occupation. This is particularly true when the focus is on economic growth and meeting labour shortages, directions recently taken in Canadian immigration policy.

- Improving Information on the Economic Implications of Immigration. The increased focus on the economic aspects of immigration presents a dilemma for policy development in that there is little clear and definitive evidence on the economic implications of immigration. On balance, the existing research suggests that the effect of immigration on GDP per capita, the wages of domestic workers, and a country's fiscal balance is small; either small positive or negative, or zero (see Lee and Miller, 2000; Kerr and Kerr, 2011; Duncan, et al, 2012; Journal of the European Economic Association special issue, 2012) This research faces serious methodological challenges and is anything but definitive. There are factors that are often excluded, such as the likely positive role of the second generation in economic growth, or immigrants' contribution to innovation. It may be that immigrants contribute significantly to economic growth (GDP per capita), but taken at face value, the general conclusions of the current research literature suggest that economic growth should not be a major consideration for immigration policy. At the very least, this research provides little guidance to policy development attempting to determine the appropriate mix and levels of immigration. This may increasingly be an area of concern to policy analysts, given the increased focus on economic immigration. Research on the economic outcomes of immigrants themselves is more definitive, and is used extensively by policy analysts when redesigning the selection systems. 
- Information Requirements to Effectively Address "Current" Labour Shortages. Policy analysts will and have made the alleviation of labour shortages a primary goal of economic immigration. As outlined in the paper, this is not new. But one fundamental issue persists; there is little real evidence to guide policy. Labour shortages related to skill or regional mismatches are extremely difficult to identify. Without proper diagnosis, an appropriate response is difficult. Shortages tend to be localized, and the statistical information available at a detailed regional or occupational level is not sufficiently reliable to accurately identify them. Many shortages are short-term in nature, driven by cyclical economic booms or temporary situations that could be resolved through labour mobility, training or wage adjustments. Furthermore, if a shortage can be identified, determining whether it is short- or long-term is difficult. One approach is to increasingly turn to employers for such information, through their hiring practices.

- Using "Arranged Jobs" to Provide Information on Labour Supply Requirement. Employers, through arranged employment, will increasingly select economic immigrants, perhaps even in the FSW program. This is in part in response to the information difficulties described above. Employers have direct information on currently available jobs. Of course, the existence of a job vacancy does not imply a labour shortage. The possible availability of Canadian workers to fill the positions perhaps with the assistance of labour mobility, training or positive wage adjustments - will have to be addressed. A "Labour Market Opinion" concluding that a Canadian worker is not available for the job will likely be needed before immigrants will be hired through arranged employment. Given current labour market information, such opinions are difficult to reliably produce, and some improvement in available information is necessary. The "arranged job" approach could potentially see a significant increase in the share of immigrants who are semi- or low-skilled. Selection criteria that address this possibility are required, especially since most occupational forecasts suggest that labour supply should not be an issue in this segment of the labour market. On the positive side, research has shown that entry earnings are higher when using arranged employment. Immigrant entry earnings will improve as a result, one important objective. On the negative side, through arranged employment employers are quite rightly concerned with immediate labour market needs and are not concerned with longer term goals such as ensuring longer-term labour market adaptability of the immigrants, high life-time immigrant earnings, or immigrant selection that will promote successful second generation educational and economic outcomes. If selection processes 
are put in place that will promote these longer-term goals and they are used in tandem with arranged employment, the result could be very positive for both short and longer-run outcomes.

- Research on the "Looming Labour Shortage". There is another labour supply issue that will increasingly attract the attention of policy analysts, a possible "looming labour shortage" associated with the retirement of the baby boom generation and the slowdown of labour force growth. Perhaps it is here that immigration can best increase GDP per capita. But again the evidence to guide policy development is weak. A few studies, mainly by the Conference Board of Canada, predict substantial generalized labour shortages within the coming 10 to 15 years, and argue that immigration levels should be increased (Conference Board of Canada, 2006, 2007). But others, such as those by the Canadian and Alberta governments (Canadian Occupational Projections System, various years; Alberta Employment and Immigration, 2010), conclude that there will not be a generalized shortage, although pockets of shortages will develop. Projecting labour supply may be tractable, but generating reliable long-term labour demand forecasts is extremely difficult (Freeman, 2006). This places policy analysts in a difficult position when attempting to determine immigration levels and the occupational mix needed to address a possible longer-run labour shortage issue.

\subsection{Simplification and Transparency of the Economic Immigrant Selection Process}

The selection of economic immigrants has become very complex in Canada. The criteria used for the selection of economic immigrants are numerous, and in some cases, not transparent. For example, the PN program has up to 60 streams to which an immigrant can apply, each with somewhat different criteria, some of which are not transparent and left to the discretion of the province at any point in time. The Ministerial Instructions program allows the CIC Minister to change selection criterion instantaneously to meet labour market needs. New programs such as the FST program and the CEC have selection criteria that are continuously evolving. If the use of arranged employment increases, selection criteria may become even less transparent and more complex. CIC has announced plans to implement in the coming year a new "Expression of Interest (EOI)" stage in the economic immigrant selection process designed to both improve economic outcomes of immigrants and reduce the applicant backlog. At some point some simplification of this system will be needed. The proposed EOI stage may be a move in that direction. As it is now understood, potential immigrants will not initially formally apply for immigration, but rather submit an "expression of interest" to immigrate. Based on mainly human capital information provided, they 
will be selected into a pool (or not), and then subsequently invited to apply to a particular program when the need for additional immigration arises. Those who have the highest score based on human capital and possibly occupational information will be selected first to apply. This will reduce the number of applications that need to be processed, thereby reducing the backlog. It will also attempt to make some basic selection criteria applicable to most programs, thereby reducing the complexity and uncertainty regarding the criteria associated with various streams, at least those in the federal programs. Little is currently known about exactly how this process will work, but simplification is likely a direction that immigration policy will take in the near future.

\subsection{Maintaining Social Cohesion and the Pro-Immigration Attitude of Canadians}

In spite of the deterioration in the economic outcomes of immigrants over the 1980s and 1990s, Canada's immigration system has produced some very positive outcomes. Perhaps the two most important are (1) the very positive educational and economic success of the children of immigrants, and (2) the lack of any significant deterioration in social cohesion related to immigration and the continued pro-immigration stance of Canadians, something almost unique in western developed economies. There are no doubt many explanations for these outcomes, but immigrant selection likely plays a role. The emphasis on the selection of economic immigrants, combined with a general belief that immigrants are needed for economic growth, supports the pro-immigration stance. The high educational attainment of immigrants is related to both the success of their children, and the positive view of immigrants. And there has been little concern regarding immigrants "stealing" the jobs of Canadians.

But cracks are starting to appear in the attitudes of Canadians towards immigration (Simmons, 2010). In Quebec in particular, politicians have expressed concern over whether the values of immigrants match those of the general population, and what constitutes "reasonable accommodation" of immigrant groups. There have been highly publicized cases in western Canada where it is believed that firms have brought in TFWs, even though Canadian workers may have been available for the jobs. This likely constitutes the first real public concern that immigrants may be stealing jobs. If "arranged employment" is increasingly used in the selection process, as seems likely, then incidents such as these may become more common. A few highly publicized events could potentially alter Canadian's view of immigration. Selection policy may have to concern itself 
with maintaining the very positive longer-term immigrant outcomes and the pro-immigration view of Canadians, goals that were not an explicit part of selection in earlier periods.

\section{Conclusion}

There are three major drivers of recent Canadian policy concerns surrounding economic immigration. The first relates to the possibility of a looming general labour shortage associated with the aging of the population, increased retirement levels and rising replacement demand. Whether such a shortage will materialize is difficult to say. Second is the desire of many Canadian provinces to receive a larger share of immigration in the belief that it will help alleviate "current" skill shortages and promote population and extensive economic growth. The third driver is the need to improve the economic outcomes of immigrants in the face of deterioration over the past three decades. This paradoxical result - poor labour market outcomes for many immigrants while simultaneously there are calls for immigration to meet "shortage" situations - has resulted in an impetus to change immigration policy and practice so as to improve outcomes. The immigration system has undergone considerable change in Canada over the past decade in response to these labour- market-based issues. They include a larger role for the provinces in the selection and integration of immigrants, increased use of the TFW program, increased selection of students completing their education in Canada, changes to the points system in the FSW program, and the development of a new FST program. These changes have increased the role of employers and educational institutions in immigrant selection, and reduced the emphasis placed on the federal points system.

In order to respond to either short run or longer run labour market demands, a country must have a means of managing immigrant flows to achieve such goals. Until recently Canada has relied on a large "economic" class of immigrants, and the points system associated with that class. More recently Canada's system is relying somewhat more on employer-based selection (i.e. pre-arranged jobs) and input from sub-national jurisdictions in the selection of "economic" immigrants. In general, the larger the immigrant flows in a country, the greater the need for a mechanism that will facilitate management.

Numerous questions remain regarding the effectiveness of immigration to achieve short and long goals and the scope for future research in the assessment of these policy changes is substantial. Early assessments of the PN and CEC programs in particular are cautiously optimistic regarding 
short-term economic outcomes. The jury is still out, however, on the longer-term consequences of these initiatives. Moreover, the use of the TFW program has increased dramatically over the last few years. Despite the relatively optimistic (but very limited) evidence regarding high skilled TFWs, little is known about the low skilled immigrants entering under this program. Research on the overall impact of the TFW program on the Canadian labour market and economy is needed. Finally, the new policy directions will increase labour market information requirements if the selection systems are to function effectively.

The rebalancing of shorter and longer run goals demands a continued focus on program evaluation. Immigrants enter Canada for the long run, even if they are selected to achieve short-run labour market goals. Hence, it is important not to limit program evaluations to the assessment of short-run outcomes of the kind that have been possible to date. A continuation of evidence-based policy development requires a long-term program of evaluation. 


\section{References:}

Alberta Employment and Immigration (2010). Alberta's Occupational Demand and Supply Outlook, 2011-2021.

Alboim, Naomi and Karen Cohl (2012). "Shaping the Future: Canada's Rapidly Changing Immigration Policies." Toronto: Maytree Foundation, available at www.maytree.com/policy.

Aydemir, Adburrahman and Mikal Skuterud (2005). "Explaining the Deteriorating Entry Earnings of Canada's Immigrant Cohorts: 1966-2000." Canadian Journal of Economics 38:2, 641-671.

Beach, Charles, Alan G. Green and Christopher Worswick (2008). "Impacts of the Point System and Immigration Policy Levers on Skill Characteristics of Canadian Immigrants" Research in Labor Economics, vol. 27, pp. 349-401. Amsterdam: Elsevier JAI Press.

Beach, Charles, Alan G. Green and Christopher Worswick (2011). Toward Improving Canada's Skilled Immigration Policy: An Evaluation Approach. Toronto: C.D. Howe Institute.

Beaujot, Rod (2003) "Projecting the future of Canada's population: assumptions, implications, and policy" Canadian Studies in Population vol.30(1), pp:1-28.

Begin, Karine, Chantal Goyette and W. Craig Riddell (2010). "Revising Canada's Immigrant Selection System: An Assessment of Recent Changes" Background paper prepared for Citizenship and Immigration Canada.

Bonikoska, Anneta, David. A. Green and W. Craig Riddell (2008). "Literacy and the Labour Market: Cognitive Skills and Immigrant Earnings". Statistics Canada Catalogue number 89-552-M No. 020. http://www.statcan.gc.ca/pub/89-552-m/89-552-m2008020-eng.pdf.

Canadian Occupational Projection System, various issues

Citizenship and Immigration Canada (2011). An Evaluation of the Provincial Nominee Program. Ottawa: CIC.

Conference Board of Canada, 2006, “Alberta’s Labour Shortages, Just the Tip of the Iceberg”. June Conference Board of Canada, 2007, “Ontario’s Looming Labour Shortages”, September

Dungan, Peter., Tony Fang and Morley Gunderson, 2012, "Macro-economic Impacts of Canadian Immigration: Results from a Macro-Model", Canadian Labour Market and Skills Research Network working paper \#106.

Ferrer, Ana, David A. Green and W. Craig Riddell (2006) "The Effect of Literacy on Immigrant Earnings.” Journal of Human Resources 41(2): 380-410.

Ferrer, Ana and W. Craig Riddell (2008). "Education, Credentials and Immigrant Earnings", Canadian Journal of Economics, vol. 41(1), pages 186-216.

Freeman Richard (2006) "Is a Great Labor Market Shortage Coming? Replacement Demand in A Global Economy" Journal of Human Resoures.

Green, Alan and David Green (1999) “The Economic Goals of Canada’s Immigration Policy: Past and Present" Canadian Public Policy 25 (December) 425-51. 
Green, David and Christopher Worswick (2010). "The Role of Labour Market Entry Effects and Returns to Foreign Experience" in Canadian Immigration: Economic Evidence for a Dynamic Policy Environment, edited by Ted McDonald, Elizabeth Ruddick, Arthur Sweetman, and Christopher Worswick. Montreal and Kingston: McGill Queen's University Press

Green, David A., and ChristopherWorswick (2012) "Immigrant Earnings Profiles in the Presence of Human Capital Investment: Measuring Cohort and Macro Effects" Labour Economics 19 (2) April: 241-259.

Hou, Feng, and Garnett Picot (2014) "Immigration, Poverty and Inequality: What is New in the 2000s?" Montreal: Institute for Research in Public Policy, forthcoming.

Kerr, Sari P. and William R Kerr (2011). “The Economic Impacts of Immigration: A

Survey"National Bureau of Economic Research (NBER), working paper \#16736

Lee, Ronald and Timothy Miller (2000). "Immigration, Social Security and Broader Fiscal Impacts," American Economic Review, May

Oreopoulos, Phillip (2011) "Why Do Skilled Immigrants Struggle in the Labor Market? A Field Experiment with Thirteen Thousand Resumes", American Economic Journal: Economic Policy, vol.3(4), pp.148-171

Pandey, Manish and James Townsend (2011). "Quantifying the effects of the provincial nominee programs" Canadian Public Policy 37 (December) 495-512.

Pandey, Manish and James Townsend (2012). "Provincial Nominee Programs: An Evaluation of the Earnings and Retention Rates of Nominees" Working Paper, University of Winnipeg, April 2012.

Picot, Garnett and Feng Hou (2009) "The Effect of Immigrant Selection and the IT Bust on the Entry Earnings of Immigrants" CLSRN WP \#29, available at:

http://www.clsrn.econ.ubc.ca/workingpapers.php.

Picot, Garnett and Arthur Sweetman (2005) "The Deteriorating Economic Welfare of Immigrants and Possible Causes." Statistics Canada, Analytical Studies Research Paper No 262.

Picot, Garnett. and Arthur Sweetman (2011), " Immigration Policy and Immigrant Economic Outcomes: Why the Differences Between Sweden and Canada", IZA Policy Paper No. 25.

Reitz, Jeffrey 2003, Educational Expansion and the Employment Success of Immigrants in Canada and the United States, 1970 to 1990, in Reitz (ed) Host Societies and the Reception of Immigrants, Centre for Comparative Studies, U. of California.

Reitz, Jeffrey 2007, Immigration Employment Success in Canada, Part II: Understanding the Decline, Int. Migration and Immigration, November

Simmons, Alan B. (2010) Immigration in Canada: Global and Transnational Perspectives, Toronto: Canadian Scholars' Press 2010

Sweetman, Arthur (2003) "Immigrant Source Country Educational Quality and Canadian Labour Market Outcomes." Statistics Canada, Analytical Studies Research Paper Series, no 234. Statistics Canada, Ottawa.

Sweetman, Arthur and Casey Warman (2009) "Temporary Foreign Workers and Former International Students as a Source of Permanent Immigration," CLSRN Working Paper 34, available at http://www.clsrn.econ.ubc.ca 
Warman, Casey (2006) "Labour market performance of foreign-born workers in Canada, evidence for landed immigrants and temporary foreign workers." Ph.D. Thesis. Carleton University: Canada Warman, Casey (2010) "The Returns to Foreign Credentials of Temporary Foreign Workers and Recently Landed Immigrants in Canada." in Canadian Immigration: Economic Evidence for a Dynamic Policy Environment, edited by Ted McDonald, Elizabeth Ruddick, Arthur Sweetman, and Christopher Worswick. Montreal and Kingston: McGill Queen's University Press, pp 209-233.

Zhang, Haimin (2012). "Centralized vs Decentralized Immigrant Selection: An Assessment of the BC Experience” Metropolis British Columbia, Working Paper No. 12-04, April 2012. 
Table 1: Selection factors under the pre-IRPA and IRPA regimes

\begin{tabular}{|l|l|l|}
\hline Criteria & Pre-IRPA points (\%) & IRPA points \\
\hline Education & $16(14)$ & 25 \\
\hline Official Language & $15(13)$ & 24 \\
\hline Experience & $8(7)$ & 21 \\
\hline Specific vocational preparation & $18(16)$ & \\
\hline Age & $10(9)$ & 10 \\
\hline Arranged Employment & $10(9)$ & 10 \\
\hline Personal Suitability & $10(9)$ & \\
\hline Adaptability & & 10 \\
\hline Relative in Canada & $5(4)$ & Under adaptability (5) \\
\hline Occupation & $10(9)$ & \\
\hline Demographic Factor & $10(9)$ & $75 / 67$ \\
\hline Total & 112 & 100 \\
\hline Pass Mark & 70 & \\
\hline
\end{tabular}

Source: Begin, Goyette and Riddell (2010) 